\title{
Correlation Between Insulin Like Growth Factor-I and Anthropometric Measurements of Premature Infants
}

\author{
Amina Abdelwahab ${ }^{1}$, Abdelmoneim Khashana², Nesma Ahmed ${ }^{3}$, Soha Younis ${ }^{4}$
}

${ }^{1}$ Dr. Amina Abdelwahab, Paediatric and Neonatology Department, Suez Canal University, Ismailia, Egypt. ${ }^{2}$ Dr. Abdelmoneim Khashana, Paediatric and Neonatology Department, Suez Canal University, Ismailia, Egypt and PEDEGO Research Center, and Medical Research Center Oulu, University of Oulu, Oulu, Finland. ${ }^{3}$ Dr. Nesma Ahmed, Paediatric and Neonatology Department, Suez Canal University, Ismailia, Egypt. ${ }^{4} \mathrm{Dr}$. Soha Younis, Clinical Pathology Department, Suez Canal University, Ismailia Egypt.

\section{Address for correspondence:}

Dr. Abdelmoneim K Khashana, MD.

Lecturer of Paediatrics and Neonatology,

Suez Canal University, Egypt

Tel No; +2 01006352403

E-mail: Abdelmoneim_khashana@hotmail.com

Acknowledgements: We would like to thank our colleagues for the valuable guidance and advice and our patients who inspired us greatly to work in this research.

Funding: Nil

Conflict of Interest: None

Permission from IRB: Yes

Ethical dilemmas faced during study: None

\section{How to cite}

Fouladinejad M. Incidence and Severity of Intra-Ventricular Haemorrhage (IVH) in Preterm Infants, Northeast of Iran. J Nepal Paediatr Soc 2016;36(1):24-27.

doi: http://dx.doi.org/10.3126/jnps.v36i1.14453

This work is licensed under a Creative Commons Attribution 3.0 License.

\begin{abstract}
Introduction: It is agreed that insulin like growth factor 1 (IGF1) influence growth. IGF-1) is a significant endocrine mediator of growth and encourages cellular propagation, survival, and differentiation. The aim of this study was to correlate insulin like growth factor 1 and anthropometric measurements in the neonatal age of the premature infants. Material and Methods: This study was performed at a level III intensive care unit at Suez Canal university hospital, Ismailia, Egypt. It is a cross sectional analytical study in the period from the March 2014 to September 2014. All cases are premature and were imperiled to history taking, clinical examination includes weight, length, head circumference and measurement of serum (IGF-1). Results: There were a total of 40 neonates. Gestational age extended from 31 to 36 weeks with a mean of $34.32 \pm 1.68$ weeks; weight ranged from 1.15 to $3.20 \mathrm{~kg}$ with a mean of $2.14 \pm 0.59 \mathrm{~kg}$ and length ranged from 37 to $49 \mathrm{~cm}$ with a mean of $43.85 \pm 3.25 \mathrm{~cm}$. Regarding neonatal gender, 21 neonates out of 40 neonates $(52.5 \%)$ were males and 19 neonates $(47.5 \%)$ were females. Mother's age ranged from 19 to 35 years with a mean of $27.47 \pm 4.46$ years. IGF1a concentration, it ranged from $13.55 \mathrm{ng} / \mathrm{ml}$ to $163.34 \mathrm{ng} / \mathrm{ml}$ with a mean of $99.64 \pm 32.43 \mathrm{ng} / \mathrm{ml}$ and there was statistically significant decrease in neonates with restricted growth when compared to non-restricted growth group $(77.67 \pm 30.92 \mathrm{ng} / \mathrm{ml}$ vs $121.62 \pm 13.64 \mathrm{ng} / \mathrm{ml}$ respectively). Conclusion: There was significant correlation between IGF-1 $\alpha$ and weight and head circumference of preterm neonates.
\end{abstract}

Key words: Insulin like growth factor -1 , preterm, anthropometric measurements

\section{Introduction}

rematurity and small for gestational age neonates are foremost causes of demise all over the globe. In 2004, these domains were the cause for 1.2 million deaths or $2 \%$ of all expiries globally. Because prematurity and small for gestational age cause mortality within the first few days of life, these conditions explain a disproportionately high $11 \%$ of all years of life lost globally ${ }^{1,2}$. 
Insulin- like growth factor-1 (IGF-1) is a significant endocrine mediator of growth and encourages cellular propagation, survival, and differentiation ${ }^{3}$. It is a single-chain polypeptide with significant homology to proinsulin. Mature IGF-1 peptide is derived from two classes of prepro IGF- 1 peptides after posttranslational processing ${ }^{4}$. IGF-1 wields feedback directive of somatostatin and growth hormone freeing the hormone, and growth hormone synthesis and discharge is additionally controlled by neurologic, metabolic, and other hormonal effects, embracing a lot of neurotransmitters and neuropeptides, which retort to such circumstances as sleep, nutritional status, stress, and exercise ${ }^{5}$.

While growth hormone may also arouse IGF-I biosynthesis in particular extra hepatic tissues, IGF-1 is adjusted independently of growth hormones in several extra hepatic tissues, thus exactly regulating their growing and role. For instance, prostaglandin E2 and parathyroid hormone augment IGF-1 biosynthesis in bone, angiotensin II provokes IGF-1 making in the cardiovascular system and nearby increased IGF-1 expression may promote compensatory renal and skeletal muscle growth and overhaul ${ }^{6}$. IGF-1 compete a vital part in familiarizing fetal growing, often in the third trimester as displayed by investigational studies ${ }^{7}$.

IGF-1 seems to be entangled in long growth restriction amid small for gestational age neonates ${ }^{8}$. Postnatal low serum levels of IGF-1 in preterm babies have been related with poor growth and retinopathy of prematurity ${ }^{9}$. The low umbilical cord serum levels of IGF-1 may be one of the reasons resulting in intra uterine growth restriction ${ }^{10}$. Insulin-like growth factors are key players in regulating growth and development of pre- and postnatal tissues. Approximately $10 \%$ of infants with intrauterine growth retardation remain small, but the reasons endure unknown ${ }^{11}$. So at our study we endeavored to correlate between insulin like growth factor 1 and anthropometric measurements in the neonatal era of the premature babies.

\section{Material and Methods}

This study was conducted at NICU, Suez Canal University Hospital, Ismailia, Egypt. The NICU is a level III intensive care nursery. Cross - sectional analytical study in the period from March 2014 to September 2014. All cases are premature (according history of date of first day of last menstrual period or Ballard score). All the studied cases were subjected to detailed history, full clinical examination includes weight, length, head circumference $(\mathrm{HC})$ and measurement of serum insulin like growth factor -1 . The study included 40 neonates aged from 1 day to $<28$ days. They were apparently free from chromosomal or genetic abnormality and not in need for major surgery. They were chosen from the neonatal intensive care, suffering from one or more of the following complaint; neonatal jaundice, respiratory distress, bad general condition and neonatal sepsis plus prematurity. All cases are premature.

\section{Results}

Regarding the characteristics of the study group; gestational age ranged from 31 to 36 weeks with a mean of $34.32 \pm 1.68$ weeks; weight ranged from 1.15 to $3.20 \mathrm{~kg}$ with a mean of $2.14 \pm 0.59 \mathrm{~kg}$ and length ranged from 37 to $49 \mathrm{~cm}$ with a mean of $43.85 \pm 3.25 \mathrm{~cm}$. There was a proportional, moderate and significant correlation between IGF-1 and premature neonatal weight. As regard length, no significant difference between premature neonates with restricted growth and those with normal growth. As regard to head circumference, it ranged from 25 to $34 \mathrm{~cm}$ with a mean of $29.43 \pm 2.28 \mathrm{~cm}$ and there was significant decrease of $\mathrm{HC}$ in premature neonates with restricted growth and those with normal growth (27.61 \pm 1.26 vs $31.25 \pm 1.45$ respectively). From these results, premature infants who have low serum IGF-1 level at greater risk for growth restriction compared to those with normal levels of serum IGF-1.

Table 1: Showing correlation between IGF-1 $\alpha$ and other descriptive parameters of the study group

\begin{tabular}{ccc}
\hline \multirow{2}{*}{ Anthropomety } & \multicolumn{2}{c}{ IGF-1a } \\
\cline { 2 - 3 } & correlation & $p$-value \\
\hline Weight & 0.44 & 0.004 \\
\hline Length & 0.19 & 0.22 \\
\hline Head circumference & 0.332 & 0.04 \\
\hline
\end{tabular}

The above table demonstrated that, there was proportional, moderate and significant correlation between IGF-1a from one side and each of weight and head circumference; these results mean that IGF-1a increased with increase of each of these parameters.

Birth weight ranged from 1.15 to $3.20 \mathrm{~kg}$ with a mean of $2.14 \pm 0.59 \mathrm{~kg}$. There was proportional, moderate and significant correlation between IGF-1 from one side neonatal weight. 


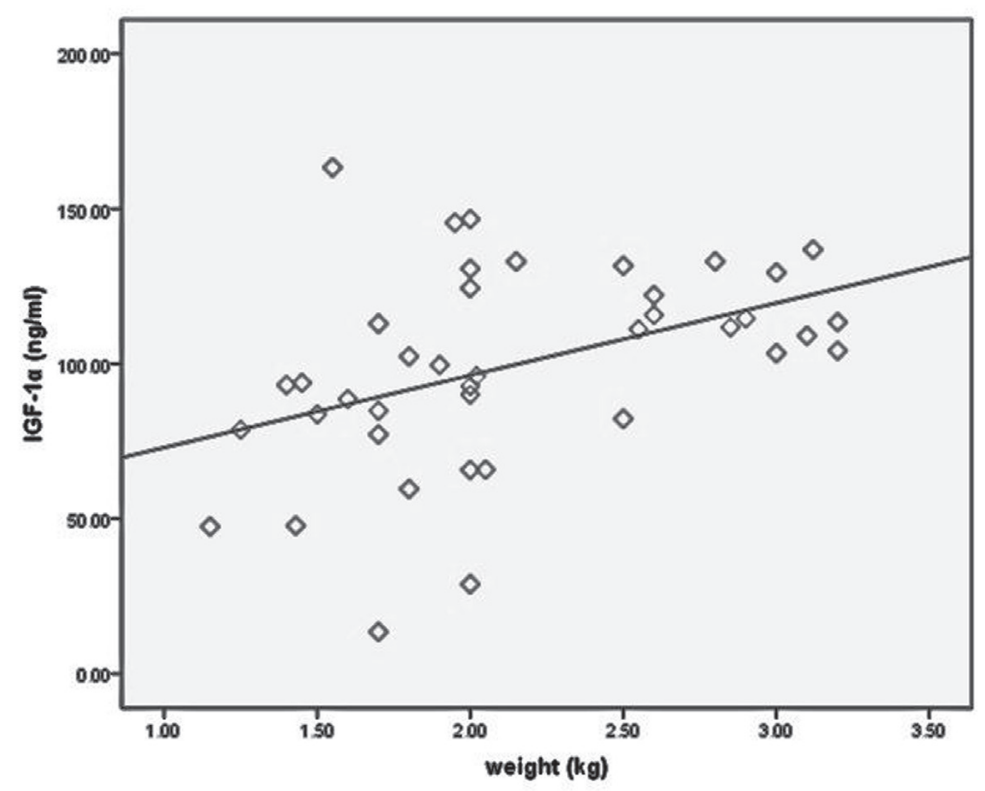

Fig 1: Graph showing correlation between IGF-1 and weight

\section{Discussion}

The knowing of endocrinal role moves frontward rapidly; new notions explode, in a lot of zones particularly insulin-resistance syndrome; and are faced by new therapeutic choices, settled on a daily basis ${ }^{12}$.

Studies of IGF-1 in IGF-1 deficiency have directed to important enhancements in the cognizing of the physiology of the growth hormone-IGF-1 axis, and have unbolted the door for the therapeutic usage of IGF-1 ${ }^{13}$. Low levels of IGF-1 are found in small for gestational age babies ${ }^{14}$. Small percentage of infants with intrauterine growth retardation (IUGR) continues small, but the reasons remain unidentified ${ }^{15}$.

IGF-I therapy should be believed as a distinguishing strategy from growth hormone treatment, averting past inadequate procedures when both $\mathrm{GH} / \mathrm{IGF}-\mathrm{I}$ therapies were considered alike. The therapeutic uses of IGF- 1 should, in principle, be limited to renovate physiological levels, but not over its normal level ${ }^{16}$.

As respect gestational age, no significant difference between premature neonates with restricted growth and those with normal growth. There was relational, moderate and significant correlation between IGF-1 from one side and each of weight, and head circumference; these results mean that IGF-1 increased with increase of each of these parameters.

As regard length, no significant difference between premature neonates with restricted growth and those with normal growth. There was significant decrease of weight in premature neonates with restricted growth and those with normal growth $(1.73 \pm 0.32$ vs $2.55 \pm 0.50$ respectively). Tamemoto et al unearthed that IGF-1 is related to length in growing preterm baby on enteral nutrition ${ }^{17}$. In another study done by Tenta and colleagues, Birth weight and birth length of neonates were positively related to serum IGF-118.

As regard to head circumference, it extended from 25 to $34 \mathrm{~cm}$ with a mean of $29.43 \pm 2.28 \mathrm{~cm}$ and there was significant decrease of $\mathrm{HC}$ in premature neonates with restricted growth and those with normal growth (27.61 \pm 1.26 vs $31.25 \pm 1.45$ respectively). In agreement with Laron et al, who described that; untreated children and adults with growth hormone deficiency have a reduced head circumference and brain growth. IGF-1 treatment induced a fast catch-up growth demonstrating the role of IGF- I on brain growth ${ }^{19}$.

From these results, premature infants who have low serum IGF-1 level at greater risk for growth restriction compared to those with normal levels of serum IGF-1. Recombinant human IGF-1 (mecasermin) has now been approved in both the US and Europe for the treatment of growth failure resulting from severe primary IGF-1 deficiency ${ }^{20}$. Also, to consider studying the relationship of restricted growth and dehydroepiandrosterone as this hormone affect the growth and disturbed in critically ill neonates ${ }^{21}$. 


\section{Conclusion}

From the present results, it was noted that the level of postnatal serum IGF-1 in the group of small for gestational age with restricted growth infants was less than that in the comparable group of normal growth premature infants. In this study serum IGF-1 level was

\section{References}

1. World Health Organization, 2008, 2004 Technical Updates of the global burden of disease 2004, World Health Organization, Geneva, available at www.who. int/...global_burden_disease/...2004update_full.pdf. Last accessed 26-1-2015.

2. Bhatia S. Biomaterials for Clinical Applications, Springer science and Business media. 2010; 259-75.

3. Bach LA. The insulin-like growth factor system: towards clinical applications. Clin Biochem Rev 2004;25(3):155-64.

4. Philippou A, Maridaki M, Halapas A, Koutsilieris M. The role of the insulin-like growth factor 1 (IGF-1) in skeletal muscle physiology. In Vivo 2007; 21(1): 45-54.

5. Rosenbloom A. Mecasermin (recombinant human insulin-like growth factor 1). See comment in PubMed Commons belowAdv Ther 2009;26(1):40-54. doi: 10.1007/s12325-008-0136-5.

6. Roith $D$ and Adamo M. Insulin-like growth factors. Encyclopedia of Endocrine Diseases. 2004; 32-5.

7. Gluckman P. Clinical review 68: the endocrine regulation of fetal growth in late gestation: the role of insulin-like growth factors. J Clin Endocrinol Metab 1995;80:1047-50.

8. Kwinta P, Klimek M, Wójcik M, Grudzień A, Drozdz $\mathrm{D}$ and Pietrzyk J. Insulin-like growth factor-1 (IGF-1) serum concentration among 7-year-old extremely low birth weight children-an indicator of growth problems, $J$ Pediatr Endocrinol Metab 2011;24(9-10): 651-7.

9. Kajantie E. Insulin-like growth factor (IGF)-I, IGF binding protein (IGFBP)-3, phosphoisoforms of IGFBP-1 and postnatal growth in very-low-birth-weight infants. Horm Res 2003;60:124-30.

10. Zhao P, Zhang $X, Y u$ C, Lu X and Wang Y. Umbilical cord serum levels of insulin-like growth factor-1, insulin and growth hormone in neonates with intrauterine growth retardation, Zhongguo Dang Dai Er Ke Za Zhi 2010;12(10):771-3. (Article in Chinese)

11. Raile K, Schneider A, Klammt J, Kratzsch J, Keller E, Seidel B, Garten A, Schmidt H, Pfäffle R and Kiess W. Clinical examples of disturbed insulin-like growth factor signaling: intrauterine and postnatal growth retardation because of mutations of the insulin-like growth factor 1 receptor gene. World J Pediatr 2006;1:14-22. found to be significantly low in neonates with growth restriction. There is a strong relationship between the serum IGF- 1 level and growth restriction in neonates. More researches are required to know more about IGF-1 role for more benefits in treating growth restricted infants as early treatment will give better results.

12. Lavin N, Leroith D, Reiter E, Ross R, Alter C, Buchanan $\mathrm{C}$ and Maheshwari H. Growth: Growth Hormone, IGF-1, and Metabolism. Current Medical Literature 2009;2(3):69-74. Accessed from; www. currentmedicalliterature.com

13. Backeljauw $P$ and Chernausek $S$. Treatment of Severe IGF-1 Deficiency with Recombinant Human IGF-1 (Mecasermin). Remedica 2009;2(3);62:70.

14. Gluckman P. Clinical review 68: the endocrine regulation of fetal growth in late gestation: the role of insulin-like growth factors. J Clin Endocrinol Metab 1995;80:1047-50.

15. Raile K, Schneider A, Klammt J, Kratzsch J, Keller E, Seidel B, Garten A, Schmidt H, Pfäffle R and Kiess W. Clinical examples of disturbed insulin-like growth factor signaling: intrauterine and postnatal growth retardation because of mutations of the insulin-like growth factor 1 receptor gene, World J Pediatr 2006;1:14-22.

16. Puche $\mathrm{J}$ and Castilla-Cortázar I. Human conditions of insulin-like growth factor-I (IGF-I) deficiency. Translational Medicine 2012;10:224.

17. Tamemoto H, Kadowaki T, Tobe K, Yagi, T., Sakura, H., Hayakawa, T, Terauchi Y., Ueki K, Yaburagi Y, Satoh S, Sekihara H, Yoshioka S, Horikoshi H, Furuta Y, Ikawa $Y$ and Kasuga $M$. Insulin resistance and growth retardation in mice made with targeted disruption of the IRS-1 gene. Nature 1994;372:182-6.

18. Tenta B, Bourgiezi I, Aliferis E, Papadopoulou M, Gounaris A and Skouroliakou M. Bone metabolism compensates for the delayed growth in small for gestational age neonates. Organogenesis 2013;9:559.

19. Laron Z, Iluz M and Kauli R. Head circumference in untreated and IGF-I treated patients with Laron syndrome: Comparison with untreated and $\mathrm{hGH}$ treated children with isolated growth hormone deficiency. Growth Horm IGF Res 2012;22(2):49-52.

20. Backeljauw $P$ and Chernausek $S$. Treatment of Severe IGF-1 Deficiency with Recombinant Human IGF-1 (Mecasermin). Remedica 2009;2(3);62-70.

21. Khashana A, Ojaniemi M, Leskinen M, Saarela T and Hallman M. Term neonates with infection and shock display high cortisol precursors despite low levels of normal cortisol. Acta Paediatr 2016;105(2):154-8. 